\title{
CONGENITAL DOPAMINE-SECRETING NEUROBLASTOMA WITH CLINICAL AND BIOCHEMICAL REMISSION
}

\author{
BY \\ E. M. BRETT*, T. E. OPPÉ, C. R. J. RUTHVEN, and M. SANDLER \\ From the Paediatric Unit, St. Mary's Hospital, London, and the Bernhard Baron Memorial Research \\ Laboratories and Institute of Obstetrics and Gynaecology, Queen Charlotte's Maternity Hospital, London
}

(RECEIVED FOR PUBLICATION DECEMBER 3, 1963)

Neuroblastoma, a disease of early childhood, may be present at birth (Wells, 1940; Potter and Parrish, 1942; Bodian, 1959; Gross, Farber and Martin, 1959; King, Storaasli and Bolande, 1961; Dargeon, 1962; Voorhess and Gardner 1962a). Such cases are more likely to undergo remission than those occurring later in life (Bodian, 1959).

Since Isaacs, Medalie and Politzer (1959) first noted an increased catecholamine production by patients with neuroblastoma, there has been a growing number of subsequent reports indicating that tumours belonging to the neuroblastomaganglioneuroma group are predominantly secretors of dopamine, the precursor of noradrenaline (Greenberg and Gardner, 1960; Sandler and Ruthven, 1960; Smellie and Sandler, 1961; Voorhess and Gardner, 1962a, b; Sourkes, Denton, Murphy, Chavez and Saint Cyr, 1963; von Studnitz, 1960; von Studnitz, Käser and Sjoerdsma, 1963; Williams and Greer, 1963; Rosenstein and Engelman, 1963).

We report the following case of congenital neuroblastoma, as the first to our knowledge in which biochemical remission has been noted to accompany 'spontaneous' tumour regression.

\section{Case Report}

L.C. was born at St. Mary's Hospital on June 14, 1962, the second child of a healthy 23-year-old woman who had been well during pregnancy. Delivery was normal, the birth weight was $7 \mathrm{lb}$. $10 \mathrm{oz}$. (3.5 kg.), and the baby breathed and cried at once but appeared rather pale.

Next day, pallor had increased and there was abdominal distension caused by firm enlargement of the liver. The spleen was not palpable. There was slight oedemia of the legs and lower abdomen. During the next few days his liver enlarged progressively to the right lower quadrant. His weight and pallor increased, the haemoglobin concentration falling from $14.5 \mathrm{~g} . / 100 \mathrm{ml}$. on the second day of life to $7 \cdot 5 \mathrm{~g}$. On the thirteenth. An intravenous

\footnotetext{
- Present address: Hospital for Sick Children, Great Ormond Street,
} London. pyelogram on the ninth day showed normal renal pelvis and calyces on both sides with possible slight downward displacement of the right kidney. A radiological skeletal survey showed no abnormality.

On the thirteenth day of life laparotomy was performed by Mr. L. Bromley who found an enlarged liver with many small nodules, white and stony hard, chiefly on the under surface of the right lobe, but also present in the left lobe. Kidneys, spleen, and intestine appeared normal. A small biopsy taken from the right lobe of the liver consisted mainly of highly vascular neoplastic tissue made up of small darkly-staining cells with rudimentary rosette formation (Fig.). A fibrillary background was present but no differentiated larger ganglionic cells were seen. The tumour was thought to be best classified as a neuroblastoma (Dr. E. Foot). Its site of origin remains unknown.

Irradiation was not considered advisable, and it was decided to give large doses of vitamin B12 intramuscularly. Treatment was started at 15 days of age with $1 \mathrm{mg}$. on alternate days, increasing four days later to $1 \mathrm{mg}$. daily.

For a time his condition remained poor, and increasing abdominal distension, due partly to increase in size of the liver and partly to ascites, caused moderate respiratory embarrassment. Oedema of the legs, abdomen, arms, and face became marked. It was noticed that the circumference of the right upper arm was slightly larger than the left. A bone-marrow biopsy from the right tibia at 24 days of age showed no abnormal cells. His haemoglobin tended to fall, and he required three small blood transfusions, the first at the time of laparotomy.

At the age of 6 days a 24-hour collection of urine was assayed for catecholamine metabolites: the output of 4-hydroxy-3-methoxymandelic acid (VMA) was $17 \cdot 4 \mathrm{mg}$. and that of 4-hydroxy-3-methoxyphenylacetic acid (HVA) $9.4 \mathrm{mg}$., using the methods, respectively, of Pisano, Crout and Abraham (1962) and of Ruthven and Sandler (1962).

Abdominal distension and oedema gradually diminished, and his haemoglobin remained at a satisfactory level, until at the age of $8 \frac{1}{2}$ weeks, he was considered well enough to be discharged home, treatment being continued with $1 \mathrm{mg}$. daily of vitamin B $12 \mathrm{im}$. At the time of discharge his liver margin reached the right lower abdominal quadrant. Two weeks afterwards, he was 


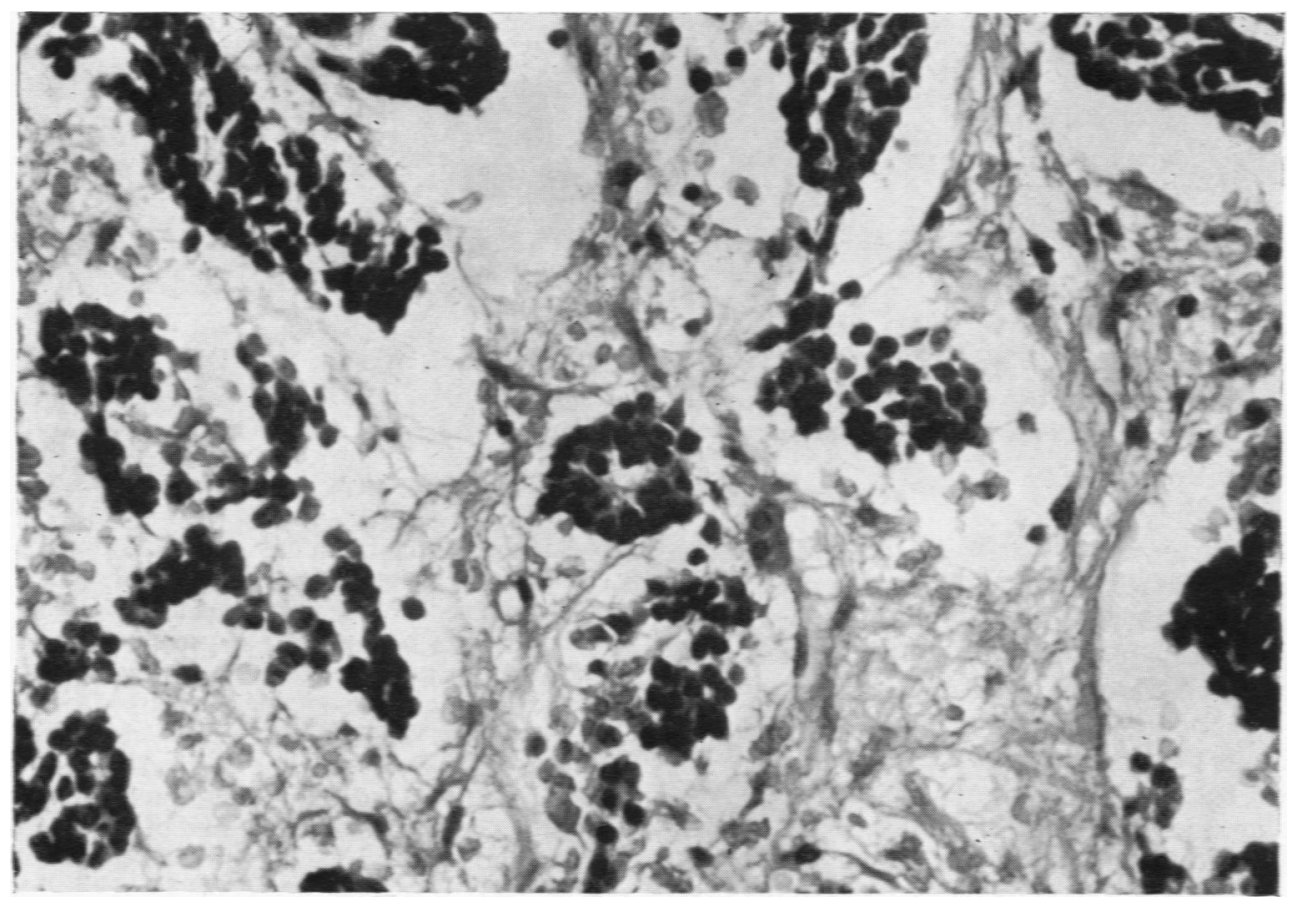

Fig.-Biopsy from right lobe of liver showing highly vascular neoplastic tissue. (H. and E. $\times 330$ ).

well and thriving with no anaemia, and the liver was found to be smaller for the first time, its edge reaching $7.5 \mathrm{~cm}$. below the right costal margin. The slight asymmetry between the upper arms persisted, the circumference on the left measuring $10 \mathrm{~cm}$. and on the right $11 \cdot 4$ $\mathrm{cm}$. The right side of the face appeared, as before, slightly larger than the left. The legs were equal in size. Apart from the differences noted, no other abnormality was found in the arms or face.

At the age of $3 \frac{1}{2}$ months bilateral inguinal swellings were detected and a few days later he was found to have incarcerated indirect inguinal herniae. These reduced spontaneously, but bilateral inguinal herniotomy was performed by Mr. Bromley: he noted, on palpating the liver through the right inguinal ring, that it was smaller than previously with smooth edge and surface, apart from a few small nodules on the inferior surface of the right lobe. The right kidney felt normal, but the right suprarenal gland was not palpated.

Post-operative progress was normal, and the child continued to thrive. At 6 months of age his liver was no longer enlarged.

Further urinary assays of VMA and HVA have been made at regular intervals and have shown a progressive fall (Table). The specimens at 3 months of age and subsequently have shown normal levels for a child in this age-group.

The child has continued to thrive with normal motor and mental development, and now, at the age of 17 months, appears a healthy happy boy.
Since the age of 3 months his B 12 injections have been reduced to alternate days, and since 7 months have been given successfully by his mother, whose intelligent co-operation has made possible his management at home.

\section{Discussion}

The treatment of neuroblastoma with vitamin B 12 is controversial. Although a dramatic response to such treatment was claimed by Bodian (1959), his findings have not been confirmed by King et al. (1961) or by Dargeon (1960). Bachmann (1962) has recently collected 1,030 cases of neuroblastoma from the literature and has shown that clinical cure, ascribed to a variety of therapeutic regimens, was claimed for $25 \%$. It appears that many of these cures were due to spontaneous regression of tumour tissue. The younger the age of onset, the more

\section{TABLE}

\begin{tabular}{ccc|c}
\hline Age (mth.) & $\begin{array}{c}\text { VMA } \\
\text { (mg./24 hr.) }\end{array}$ & $\begin{array}{c}\text { HVA } \\
\text { (mg-/24 hr.) }\end{array}$ \\
\cline { 2 - 3 } & 6 days. & 17.4 & $9 \cdot 4$ \\
11 & $\cdots$ & 6.5 & 7.5 \\
3 & $\cdots$ & 1.9 & 1.0 \\
9 & $\cdots$ & 1.0 & 1.0 \\
13 & $\cdots$ & 0.8 & 0.6 \\
15 & $\cdots$ & 1.9 & 2.5 \\
17 & $\cdots$ & 1.8 & 2.4 \\
\hline
\end{tabular}


likely is such regression to occur. It is therefore not possible in the present case to claim more than a fortuitous association between vitamin B 12 treatment and the clinical outcome.

Several workers have used the biochemical activity of the tumour, as reflected by the urinary excretion of catecholamines and their metabolites, to chart the clinical progress of the patient (Greenberg and Gardner, 1960; von Studnitz, 1960; 1962; von Studnitz et al., 1963; Smellie and Sandler, 1961; Voorhess and Gardner, 1961, 1962a, b; Bettex and Käser, 1962; Kontras, 1962; Young, Steiker, Bongiovanni, Koop and Eberlein, 1963; Sourkes et al., 1963; Rosenstein and Engelman, 1963; Williams and Greer, 1963). Williams and Greer (1962, 1963) have pointed out from their own experiences and from a study of the literature that the measurement of HVA, the major metabolite of dopamine, and of VMA, the major metabolite of noradrenaline, provide sufficient information to make a diagnosis in most cases of this secreting tumour.

In the patient described here, comparatively vast concentrations of these metabolites were excreted in the urine initially. Coinciding with an improvement in the patient's clinical state and with tumour regression, levels gradually fell to normal, providing valuable biochemical confirmation of apparent clinical cure.

\section{Summary}

A case of congenital neuroblastoma of unknown origin with multiple hepatic metastases is reported. Regression of the tumour was associated with a return to normal of the initially very high levels of 4-hydroxy-3-methoxymandelic acid (VMA) and 4-hydroxy-3-methoxyphenylacetic acid (HVA) in the urine. These values have remained within normal limits up to the age of 17 months.

\section{REFERENCES}

Bachmann, K.-D. (1962). Das Neuroblastoma sympathicum. Klinik und Prognose von 1030 Fällen. Z. Kinderheilk., 86, 710. Bettex, M. and Käser, H. (1962). Diagnostic and prognostic value of the determination of urinary output of vanillylmandelic acid in tumours of sympathetic nervous system. Arch. Dis. Childh., 37, 138.

Bodian, M. (1959). Neuroblastoma. Pediat. Clin. N. Amer., 6, 449.
Dargeon, H. W. (1960). Problems in the prognosis of neuroblastoma. Amer. J. Roentgenol., 83, 551.

(1962). Neuroblastoma. J. Pediat., 61, 456.

Greenberg, R. E. and Gardner, L. I. (1960). Catecholamine metabolism in a functional neural tumor. J. clin. Invest., 39, 1729.

Gross, R. E., Farber, S. and Martin, L. W. (1959). Neuroblastoma sympatheticum. A study and report of 217 cases. Pediatrics, 23, 1179.

Isaacs, H., Medalie, M. and Politzer, W. M. (1959). Noradrenalinesecreting neuroblastomata. Brit. med. J., 1, 401.

King. R. L., Storaasli, J. P. and Bolande, R. P. (1961). Neuroblastoma: review of twenty-eight cases and presentation of two cases with metastases and long survival. Amer.J. Roentgenol., 85, 733.

Kontras, S. B. (1962). Urinary excretion of 3-methoxy-4-bydroxymandelic acid in children with neuroblastoma. Cancer (Philad.), $15,978$.

Pisano, J. J., Crout, J. R. and Abraham, D. (1962). Determination of 3-methoxy-4-hydroxymandelic acid in urine. Clin. chim. Acta, $7,285$.

Potter, E. L. and Parrish, J. M. (1942). Neuroblastoma, ganglioneuroma and fibroneuroma in a stillborn fetus. Amer. J. Path., $18,141$.

Rosenstein, B. J. and Engelman, K. (1963). Diarrhea in a child with a catecholamine-secreting ganglioneuroma. Case report and review of the literature. J. Pediat., 63, 217.

Ruthven, C. R. J. and Sandler, M. (1962). The estimation of homovanillic acid in urine. Biochem. J., 83, 30P.

Sandler, M. and Ruthven, C. R. J. (1960). 3-methoxy-4-hydroxymandelic acid excretion in phaeochromocytoma. In Ciba Foundation Symposium on Adrenergic Mechanisms, ed. J. R. Vane, G. E. W. Wolstenholme and M. O'Connor, p. 40. Churchill, London.

Smellie, J. M. and Sandler, M. (1961). Secreting intrathoracic ganglioneuroma. Proc. roy. Soc. Med., 54, 327.

Sourkes, T. L., Denton, R. L., Murphy, G. F., Chavez, B. and Saint Cyr, S. (1963). The excretion of dihydroxyphenylalanine, dopamine, and dihydroxyphenylacetic acid in neuroblastoma. Pediatrics, 31, 660.

Studnitz, W. von (1960). Methodische und klinische Untersuchungen über die Ausscheidung der 3-Methoxy-4-hydroxymandelsāure im Urin. Scand. J. clin. Lab. Invest., 12, Suppl, 48.

- (1962). Ober die Ausscheidung der 3-Methoxy-4-hydroxyphenylessigsāure (Homovanillinsāure) beim Neuroblastom und anderen neuralen Tumoren. Klin. Wschr., 40, 163.

- Kāser, H. and Sjoerdsma, A. (1963). Spectrum of catecholamine biochemistry in patients with neuroblastoma. New Engl. J. Med., 269, 232.

Voorhess, M. L. and Gardner, L. I. (1961). Urinary excretion of norepinephrine, epinephrine and 3-methoxy-4-hydroxymandelic acid by children with neuroblastoma. J. clin. Endocr., 21, 321. (1962a). Studies of catecholamine excretion by children with neural tumors. ibid., 22, 126.

- (1962b). The value of serial catecholamine determinations in children with neuroblastoma. Report of a case. Pediatrics, 30, 241.

Welk, H. G. (1940). Occurrence and significance of congenital malignant neoplasms. Arch. Path., 30, 535.

Williams, C. M. and Greer, M. (1962). Diagnosis of neuroblastoma by quantitative gas chromatographic analysis of urinary homovanillic and vanilmandelic acid. Clin. chim. Acta., 7, 880.

- (1963). Homovanillic acid and vanilmandelic acid in diagnosis of neuroblastoma. J. Amer. med. Ass., 183, 836.

Young, R. B., Steiker, D. D., Bongiovanni, A. M., Koop, C. E. and Eberlein, W. R. (1963). Urinary vanilmandelic acid (VMA) excretion in children: use of a simple semi-quantitative test. J. Pediat., 62, 844. 